\title{
PENYELENGGARAAN LAYANAN KONSELING PERORANGAN DENGAN PENDEKATAN KONSELING RASIONAL EMOTIF BEHAVIOR
}

\author{
Aldila Fitri Radite Nur Maynawati ${ }^{1}$, Awik Hidayati ${ }^{2}$. \\ ${ }^{1}$ FKIP, Universitas Veteran Bangun Nusantara, Sukoharjo \\ aldila.fitri.rnm@gmail.com \\ ${ }^{2}$ FKIP, Universitas Veteran Bangun Nusantara, Sukoharjo \\ awik.hidayati30@gmail.com
}

\begin{abstract}
Abstrak
Penelitian ini dilatar belakangi dari hasil observasi di sekolah terhadap pelaksanaan layanan konseling perorangan rasional emotif behavior. Tujuan penelitian ini adalah mengetahui penyelenggaraan layanan konseling perorangan dengan pendekatan konseling rasional emotif behavior di SMA Negeri se-Kabupaten Sukoharjo mulai dari perencanaan, pelaksanaan, evaluasi, serta hambatan-hambatannya. Penelitian ini menggunakan metode penelitian survai. Dengan pengambilan populasi di SMA Negeri se-Kabupaten Sukoharjo. Penelitian ini menggunakan teknik cluster sampling (area sampling) teknik ini digunakan karena daerah atau strata digunakan untuk menentukan sampel objek yang akan diteliti atau sumber data sangat luas. Hasil penelitian ini membuktikan bahwa guru bimbingan konseling dalam melaksanakan layanan konseling perorangan rasional emotif behavior sudah menggunakan perencanaan, namun disesuaikan dengan permasalahan siswa. Ketika pelaksanaan guru bimbingan konseling belum mengikuti tahaptahap konseling rasional emotif yang ada, dan belum mengetahui teknik-teknik dalam konseling tersebut. Guru bimbingan konseling masih kurang dalam mengevaluasi layanan konseling perorangan rasional emotif behavior, namun dalam pelaporannya sudah melaporkan kepada Kepala Sekolah. Hambatan dalam pelaksanaan layanan tersebut karena terkendala jam mengajar, serta fasilitas sekolah.
\end{abstract}

Keywords: Penyelenggaraan, Layanan, Konseling, Rational Emotif Behavior.

\begin{abstract}
This research is based on the results of school observations on the implementation of individual rational emotive behavior counseling services. The purpose of this study is to know the implementation of individual counseling services with rational emotive behavior counseling approach in SMA Negeri as Sukoharjo District starting from planning, implementation, evaluation, and constraints. This research uses survey method. With population taking in SMA Negeri as Sukoharjo District. This study uses cluster sampling technique (area sampling) This technique is used because the area or strata used to determine the sample object to be studied or data source is very broad. The results of this study proves that counseling teachers in implementing individual counseling services rational emotive behavior has been using planning, but tailored to the problems of
\end{abstract}


students. When the implementation of counseling teachers has not followed the existing emotional rational counseling stages, and has not yet known the techniques in the counseling. Teacher guidance counseling is still lacking in evaluating individual rational emotive behavior counseling services, but in reporting it has been reported to the Principal. Obstacles in the implementation of these services because constrained hours of teaching, as well as school facilities.

Keywords: Organization, Service, Counseling, Rational Emotive Behavior

\section{PENDAHULUAN}

Siswa usia remaja adalah masa transisi menuju masa dewasa. Dalam perkembangannya banyak ditemui permasalahan di antaranya obatobatan, alkohol, seks bebas, perkelahian, bullying, membolos, nilai akademik rendah dan lain-lain (Santrock, 2002: 19-20).

Layanan konseling perorangan sebagai salah satu layanan bimbingan dan konseling dapat diberikan di sekolah ataupun di luar sekolah. Penyelenggaraan layanan konseling perorangan di sekolah memusatkan pada perkembangan diri siswa. Dengan adanya layanan konseling perorangan, siswa diharapkan mampu mengembangkan potensi yang dimilikinya.

Penyelenggaraan layanan konseling perorangan akan berjalan sesuai harapan, bila dimulai dari perencanaan, pelaksanaan hingga evaluasi yang tersusun dengan baik. Perencanaan layanan konseling perorangan dapat disusun melalui program tahunan, semesteran, bulanan, mingguan, maupun harian yang berupa SATLAN (satuan layanan). Pelaksanaan layanan konseling perorangan dapat dilakukan pada jam pembelajaran maupun di luar jam pembelajaran, dapat pula dilakukan di dalam ruangan maupun di luar ruangan. Evaluasi layanan konseling perorangan dapat berupa Laiseg (laporan segera) secara lisan maupun tertulis, Laijapen (laporan jangka pendek), dan Laijapang (laporan jangka panjang).

Penyelenggaraan layanan konseling perorangan menjadi tugas utama guru bimbingan konseling. Namun, yang terjadi di sekolahsekolah khususnya Sekolah Menengah Atas (SMA) Negeri di kabupaten Sukoharjo, guru bimbingan konseling belum dapat mengoptimalkan layanan konseling perorangan khususnya konseling rasional emotif behavior. Hal ini karena konseling perorangan dengan pendekatan rasional emotif behavior dirasa sulit untuk dilaksanakan bagi guru bimbingan konseling. Dari perencanaan guru bimbingan konseling mungkin telah optimal dalam merencanakannya, akan tetapi pada proses pelaksanaan konseling perorangan itu sendiri cenderung tidak terlaksana sesuai perencanaan. Guru pembimbing di kabupaten Sukoaharjo pun cenderung kurang terampil dalam melaksanakan 


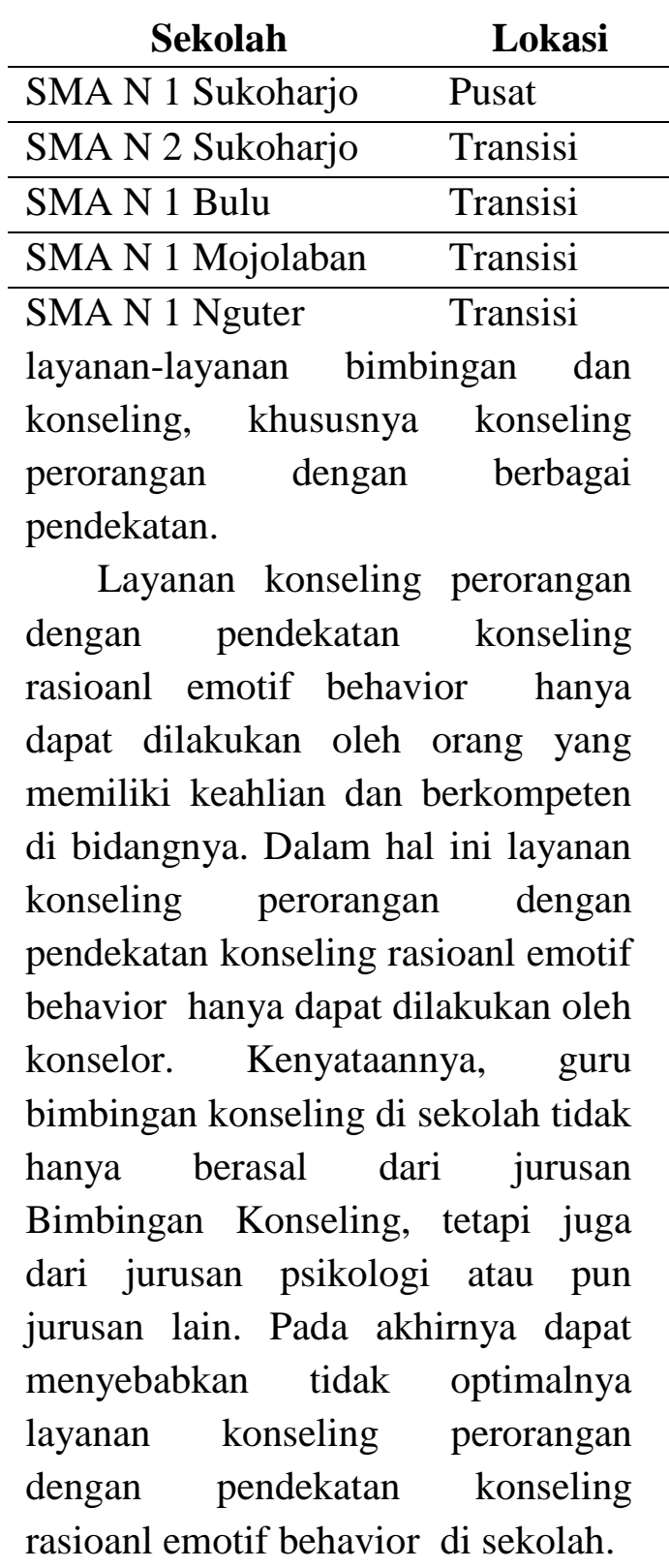

\section{METODE PENELITIAN}

Metode yang digunakan dalam penelitian ini adalah metode survai. Metode survai yaitu penelitian yang dimaksudkan untuk pengukuran yang cermat terhadap fenomena sosial tertentu (Singarimbun, 2006).

Rancangan penelitian dalam penelitian ini adalah pertama dengan pengambilan sampel. Populasi dari penelitian ini adalah SMA Negeri Se-Kabupaten Sukoharjo Tahun Ajaran 2016/2017, sedangkan sampel dari penelitian ini yaitu:

Tabel 1. Daftar sampel sekolah

Setelah pemilihan sampel yang akan dijadikan penelitian, peneliti mengambil 50 siswa (dengan setiap sekolah 10 siswa), dan semua guru bimbingan dan konseling yang ada di sekolah tersebut.

Sumber data dalam penelitian ini adalah siswa dan guru bimbingan konseling di SMA Negeri seKabupaten Sukoharjo. Teknik pengumpulan data menggunakan angket dan wawancara. Teknik analisis data yang digunakan dengan rumus Persentase:

$$
P=\frac{n}{N} X 100 \%
$$

dengan keterangan: $\mathrm{P}=$ Persentase, $\mathrm{n}=$ Skor nyata, dan $\mathrm{N}=$ Skor Ideal.

Kisi-kisi angket berdasarkan konsep yang sudah ada, dimulai dari perencanaan layanan konseling perorangan, pelaksanaan, evaluasi hingga pada hambatannya. Angket yang digunakan adalah angket tertutup, menggunakan lima alternatif jawaban, yaitu Sangat Sesuai, Sesuai, Tidak Bisa Menentukan dengan Pasti, Kurang Sesuai dan Tidak Sesuai. Pedoman wawancara juga disusun melalui kisi-kisi dimulai dari perencanaan layanan konseling perorangan 


rasional emotif $\quad$ behavior,
pelaksanaan,
hambatan.

\section{HASIL DAN PEMBAHASAN}

Berdasarkan hasil analisis angket bagi guru bimbingan konseling di
SMA Negeri se-Kabupaten Sukoharjo tahun 2016/2017 tentang penyelenggaralaan layanan konseling perorangan rasional emotif behavior didapat hasil dengan gambar sebagai berikut:

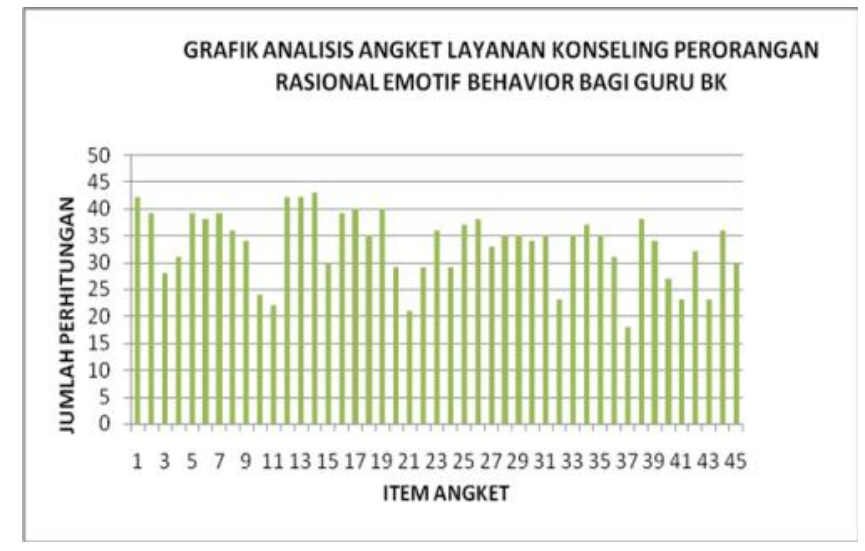

Gambar 1. Grafik Analisis angket layanan konseling perorangan rasional emotif behavior bagi guru BK.

Dari hasil angket tersebut didapat informasi bahwa Guru bimbingan dan konseling memiliki basic ilmu bimbingan dan konseling. Pada tahap awal sebelum konseling, guru bimbingan konseling mengajak, merekrut serta meyakinkan siswa untuk kegiatan layanan konseling perorangan dengan pendekatan konseling rasional emotif behavior. Namun, guru bimbingan konseling belum bisa mengidentifikasi masalah siswa mana saja yang bisa dibawa ke dalam layanan konseling perorangan dengan pendekatan konseling rasional emotif behavior.

Guru bimbingan dan konseling di Kabupaten Sukoharjo dalam menentukan jadwal konseling tidak sesuai jadwal yang telah dibuat, mereka mampu menentukan ruang konseling serta merancang posisi yang nyaman bagi siswa dalam konseling. Ada beberapa guru yang tidak sempat memberitahukan kepala sekolah terkait kegiatan layanan konseling perorangan. Guru bimbingan konseling juga kurang memperhatikan biodata klien layanan konseling perorangan.

Suatu hal yang baik bahwa guru bimbingan konseling sudah mampu membina hubungan baik dengan klien, serta mengidentifikasi masalah terlebih dahulu. Ketika dalam tahap pelaksanaan, guru bimbingan dan 
konseling belum mampu mengidentifikasi activating event dan mengeksplorasi belief klien. Guru bimbingan konseling sudah mampu mereview ulang konsekuensi negatif pada perilaku emosi dalam konseling rasional emotif behavior pun bersama klien mendialogkan apa yang ingin dicapai klien dalam konseling, serta pemahaman akan keyakinan irasionalnya. Guru bimbingan konseling tidak menunjukkan contoh $\mathrm{ABC}$ dalam kasus sehari-hari. Guru bimbingan konseling juga tidak menunjukkan kepada klien dalam memelihara gangguan perilaku dan emosi dengan menjaga pemikiran irasional. Dalam memastikan perubahan keyakinan irasional klien, guru bimbingan konseling belum menerapkannya. Selama pelaksanaan, guru bimbingan konseling juga mendiskusikan PR dan perubahan yang terjadi pada pertemuan berikutnya. Bersama klien guru bimbingan konseling mendiskusikan keyakinan irasional yang ada di masyarakat.

Sayangnya, setelah selesai konseling guru bimbingan konseling belum optimal dalam melaksanakan evaluasi secara verbal maupun non verbal dikarenakan beberapa hal. Namun di akhir guru bimbingan dan konseling tetap memberikan laporan pelaksanaan kepada kepala sekolah terkait konseling perorangan rasional emotif behavior yang sudah dilaksanakannya.
Sedangkan berdasarkan analisis angket pada siswa didapat informasi bahwa siswa diajak dan didekati guru bimbingan konseling untuk mengikuti layanan konseling perorangan pedekatan konseling rasional emotif behavior walaupun di sisi lain siswa masih merasa kurang nyaman dengan guru bimbingan konseling untuk direkrut dalam konseling perorangan. Siswa merasa waktu pelaksanaan konseling kurang sesuai dengan waktu yang sudah dijadwalkan.

Dalam proses pelaksanaan siswa mengisi presensi dalam kegiatan layanan konseling perorangan pendekatan konseling rasional emotif, siswa juga tidak diberitahu adanya biodata peserta layanan. Sebelum dilaksanakan konseling, siswa diberitahu terlebih dahulu oleh guru bimbingan konseling. Siswa merasa kurang mengetahui kalau guru bimbingan konseling melaksanakan konseling perorangan rasional emotif behavior sudah sesuai tahapannya.

Siswa kurang tahu jika tujuan konseling perorangan adalah untuk memandirikan siswa. Guru bimbingan konseling telah menjelaskan tentang keyakinan irasional kepada siswa. Siswa merasa tahu ketika guru bimbingan konseling melaksanakan evaluasi. Siswa kurang mengetahui bahwa guru bimbingan konseling menggunakan teknik dalam layanan konseling perorangan pendekatan 
rasional emotif behavior. Selama konseling siswa merasa sulit untuk mengikuti layanan dan masih merasa takut daam mengungkapkan masalah pribadinya. Namun siswa merasa senang mengikuti konseling perorangan.

Sedangkan informasi yang didapat dari hasil wawancara kepada guru bimbingan dan konseling yaitu guru bimbingan konseling sebenarnya ingin memberikan layanan konseling rasional emotif behavior, namun kendalanya ada pada jam pelajaran bimbingan konseling di sekolah. Juga, guru bimbingan konsleing lebih sering menggunakan pendekatan lain, yaitu konseling behavior. Sejatinya konselor sudah mengetahui apa itu konselinng rasional emotif behavior, namun guru bimbingan konseling masih merasa belum yakin dalam melaksanakan konseling rasional emotif. Selain itu, fasilitas sekolah yang kurang meadai seperti ruang konseling perorangan yang kurang kondusif untuk melaksanakan konseling perorangan.

\section{SIMPULAN}

Hasil penelitian ini membuktikan bahwa guru bimbingan konseling dalam melaksanakan layanan konseling perorangan rasional emotif behavior sudah menggunakan perencanaan, namun disesuaikan dengan permasalahan siswa. Ketika pelaksanaan guru bimbingan konseling belum mengikuti tahap-tahap konseling rasional emotif yang ada, dan belum megetahui teknik-teknik dalam konseling tersebut. Guru bimbingan konseling masih kurang dalam mengevaluasi layanan konseling perorangan rasional emotif behavior, namun dalam pelaporannya sudah melaporkan kepada Kepala Sekolah. Hambatannya dalam pelaksanaan layanan tersebut karena terkendala jam mengajar, serta fasilitas sekolah.

\section{DAFTAR PUSTAKA}

Ellis, Albert. (2007). Terapi REB Agar Hidup Bebas Derita. (Terjemahan Mahyuddin, Ikramullah). Yogyakarta: B first.

Mashudi, E.A. (2016). Konseling Rational Emotive Behavior dengan Teknik Pencitraan untuk Meningkatkan Resiliensi Mahasiswa Berstatus Sosial Ekonomi Lemah. Jurnal Psikopedagogia, 5(1), 66-78. Prayitno. (2004). Layanan Bimbingan Kelompok Konseling Perorangan: Seri Layanan Konseling. Padang: Jurusan BK FIP Universitas Negeri Padang.

Rumabar, Obeth. (2008). Penggunaan Terapi Rational Emotive Behaviour Therapy (REBT) untuk Mengubah Self-esteem Rendah Mahasiswa STIPAK "Duta Harapan" Malang (Studi Pra-eksperimental) (Tesis, Universitas Negeri Malang). 
116 Jurnal Ilmiah Counsellia, Volume 7 No. 2, Nopember 2017 : 110 - 116

Santrock, John W. (2002). Life-Span

Development Perkembangan

Masa Hidup Jilid 1.

(Terjemahan Chusairi,

Achmad dan Juda Damanik).

Jakarta: Erlangga.

Sumairah, dkk. (2017). Penerapan

Konsleing Rasional Emotif

Perilaku (REP) untuk

Meningkatkan Kepercayaan

Diri Siswa Kelas VIII SMP

Negeri 1 Sampang. Jurnal

BK UNESA, 7 (1), 1-6.

Thahir, Andi. (2016). Pengaruh

Konseling Rational Emotif

Behavioral Therapy (REBT)

dalam Mengurangi

Kecemasan Peserta Didik

Kelas VIII SMP Gajah Mada

Bandar Lampung. Konseli:

Jurnal Bimbingan dan

Konseling, 3(2), 79-96. 